DOI https://doi.org/10.36059/978-966-397-116-2/243-257

\title{
THE DIRECTIONS OF IMPROVEMENT \\ OF NATIONAL LEGISLATION: FROM THE COMMAND- \\ CONTROLLED SYSTEM TO THE MODERN DEMOCRATIC SOCIAL LAW-GOVERNED STATE
}

\section{Petkov S. V.}

\section{INTRODUCTION}

After proclaiming independence in Ukraine $^{1}$ the period of large-scale reforms began, which was supposed to be completed by the transformation of the Soviet-pattern Ukraine into the European state. Having adopted the Constitution of Ukraine in 1996, the reformative efforts to introduce human centered ideology gained an additional impulse. Article 5 of the Constitution of Ukraine stipulates that "the bearer of sovereignty and the only source of power in Ukraine is the people. People exercise power directly and through the bodies of state power and local self-government", and Article 6 of the Constitution of Ukraine stipulates that "state power in Ukraine is exercised on the basis of its division into legislative, executive and judicial"2. Just in order to bring the state power in Ukraine in the compliance of its actual state (with the remained elements of the Soviet system) with the legal state (enshrined in the Constitution of an independent Ukraine), the administrative reform was initiated in 1998. In fact, it should have become the basis for reforming not only administrative legislation, but also the entire public law in Ukraine.

The Constitution of Ukraine laid the basis for the development of Ukraine as a highly developed, legal, civilized European state with a high standard of living, culture and democracy, in which the principle of the supremacy of law acts and all public relations are based on legal orders. Article 3 of the Constitution of Ukraine stipulates that "human rights and freedoms and their guarantees determine the content and orientation of the state. The state is responsible to a person for its activity. The assertion and

\footnotetext{
${ }^{1}$ Про проголошення незалежності України : Постанова Верховної Ради Української РСР [Електронний ресурс]. - Режим доступу: http://gska2.rada.gov.ua/.

2 Конституція України // Відомості Верховної Ради України. - 1996. - № 30. - Ст. 141.
} 
guarantee of human rights and freedoms is the main duty of the state" ${ }^{\text {. }}$ The basis of democratic development is the person's responsibility towards society, and the state towards citizens.

So, is it a true state in our country if we talk about an average citizen? If during the collapse of the Soviet Union in the early 1990s, Ukraine claimed to be a country in the top ten of the most developed countries in the world, and now the irresponsible national and foreign policy carried out by the authorities led to a decline in the economic development, an increase in the amount of external debt, and the impoverishment of the population. Corruption in the state apparatus has led to the loss of territories, the emergence of armed conflicts, and state property theft. The genocide has begun against Ukrainian people, who in accordance with Article 5 of the Constitution of Ukraine are "the bearer of sovereignty and the only source of power". In 1993, the population of Ukraine made 52.2 million people, now it is 42.8 million people. If in 2014 the number of births made 314 255, then in 2015 it was 273884 newborns. Thousands of Ukrainians go abroad in search of a better life outside of the Motherland.

\section{Systematization and Codification of Ukrainian Legislation is the Basis for Democratic Changes}

We can no longer ignore the actual state of things. And this state is characterized by the negation of elementary axioms of the law theory. We are currently in a state of collapse and disintegration characterized by such terms as "legal nihilism of citizens", "irresponsibility of officials", "insignificance of legal norms", "helplessness of civil society", etc.

The structuring of legislation is a guarantee of its implementation effectiveness. The division into legislation branches and sub-branches, the internal structure of norms must be clear, transparent and unified, regardless of the legal relations regulated by it, so, it must be algorithmic. During the formation and operation of mono-structural Soviet legislation (without division into the legislation of public and private law) there was a chaotic accumulation of laws and by-laws, which created a situation in Ukraine when ordinary citizens, entrepreneurs could not work in accordance with the current legislation due to the complexity and nontransparency of the state regulation. Finally, legislation and the

\footnotetext{
${ }^{3}$ Там само.
} 
bureaucracy hamper the development of the state. As a result, legislation and bureaucratic apparatus hinder the development of the state.

Traditionally, the main criterion for the unification of administrative and legal norms and their distribution in structural units is the subject of legal regulation ${ }^{4}$. According to this, the system constructed provides for separation of legal institutions, united into the general, special and specific parts of administrative law. The general part of administrative law includes norms (including legal principles) that are in force in all fields of organization and functioning of public administration. So, it unites the most typical, general things in the legal regulation of the filed mentioned. A special part of administrative law is the norms governing the provision of administrative public order. A special part of administrative law is an administrative delinctology.

At present the system of administrative law can be represented as follows.

The general part of administrative law - the essence of administrative law defines: the conceptual framework; object of administrative law; administrative-legal relations; principles of state administration; legal status of administrative law subjects; social agreement; administrativelegal method; forms and functions; administrative law norms ${ }^{5}$.

The special part of administrative law - the administrative activity defines: administrative-legal regimes (public emergency, state of martial law, customs, etc.); administrative services; state service; disciplinary responsibility; protection of the rights of citizens; administrative enforcement; administrative proceedings.

Special part of administrative law - administrative delictology defines: administrative responsibility; administrative misconduct; counteraction to misconduct committed by officials; composition of administrative misconduct; proceedings in cases of administrative misconduct; the status of a public servant; system of supervisory bodies.

In Ukraine the issues of administrative reform went beyond the theoretical work long time ago and gained practical - political, scientific, and social - relevance. After the proclamation of Ukrainian independence, there was a period of wide-ranging reforms that had already started during

\footnotetext{
${ }^{4}$ Остапенко О.І. Адміністративне право : : навч. посіб / О.І. Остапенко, 3.Р. Кісіль, М.В. Ковалів та ін. - К. : Правова Сдність, 2008. - 536 с.

5 Васильев А.С. Административное право Украины: (Общая часть ) : учеб.пособие / А.С. Васильев . - 2-е изд . - Харків : Одиссей, 2001 . - 287 с.
} 
the Soviet Union existence ${ }^{6}$. Together with adoption of the Constitution of Ukraine in 1996 the reformative efforts gained an additional impulse ${ }^{7}$.

The coverage of the administrative law subject under modern conditions requires a detailed analysis of the achievements of the legal science in general. Recognizing the changes in legal science that have taken place and is taking place in recent years, we emphasize that jurisprudence as a science does not perform, as it would be desirable for politicians of the past and present, the role of servants in the state, but vice versa, by means of legal mechanisms, adjusts the activity of the state and directs society development. But unfortunately, in a situation where society and public institutions replace the spirit of law with the letter of law, when distorted morality becomes the basis for criminal activity, the law of a particular country also loses partially its true form and meaning. Formulas and algorithms that are basic in the law theory, regardless of the society structure, where the law exists, are unchanged. Studying the fractal structure of law and introduction of ideas into practical activity are an urgent task of the present.

The systematization of Ukrainian legislation, in fact, is the first step in bringing it to the international standards. Actually, work must be carried out in two directions: the external and internal structuring of legislation.

The external structuring of legislation consists in bringing to the logical construction of the legislation branches and harmonization of the national legislation with the international law.

The first step in such work is systematization of legislation, creation of electronic databases of legal acts in accordance with socio-economic areas $^{8}$. Analysis of normative-legal acts to detect duplication in them, collisions, gaps and, consequently, the cancellation of those acts that do not comply with the provisions of the current legislation.

This task can not be carried out without transferring norms from one normative legal act to another. At the same time, attention should be paid to the fact that there is already a tendency towards the division of public relations into areas and their respective normative - legal regulation.

\footnotetext{
${ }^{6}$ Про проголошення незалежності України : Постанова Верховної Ради Української РСР [Електронний ресурс]. - Режим доступу: http://gska2.rada.gov.ua/.

${ }^{7}$ Конституція України // Відомості Верховної Ради України. - 1996. - № 30. - Ст. 141.

${ }^{8}$ Коломоєць Т. О. Адміністративне право України. Академічний курс : підруч. / Т. О. Коломоєць. К. : Юрінком Інтер, 2011. - 576 с.
} 
Already there was a transfer of norms from the Code on Administrative Offences of Ukraine to the Customs Code of Ukraine. But now misconduct is called administrative and customs law violation, while it is about customs misconduct.

Transfer of norms is the transfer of a legal norm or group of legal norms from one normative legal act to another in accordance with the subject of legal regulation. A transfer may take place between normativelegal acts of different levels. The criterion of transfer activity in the law should be the domain of public relations, in which the relevant legal acts carry out regulation (the subject of legal regulation). At present, such transfer is necessary; it will give an opportunity to avoid collisions, duplications and significantly reduce the number of regulatory acts governing the legal relations in various domains of public life.

Similarly, it is necessary to transfer the norms governing responsibility for misconduct contained in the Code on Administrative offences of Ukraine to other current codes:

Customs Code of Ukraine dated March 13, 2012 № 4495-VI // Bulletin of the Verkhovna Rada of Ukraine. - 2012.- № 44-45, № 46-47, № 48. - Art. 552;

Code of Mineral Resources dated July 27, 1994 No. 132/94-BP // Bulletin of the Verkhovna Rada of Ukraine. - 1994. - № 36. - Art. 340;

Land Code of Ukraine dated October 25, 2001 No. 2768-III // Bulletin of the Verkhovna Rada of Ukraine. - 2002. - № 3-4. - Art. 27;

Water Code of Ukraine dated June 06, 1995, No. 213/95-BP // Bulletin of the Verkhovna Rada of Ukraine. - 1995. - № 24. - Art. 189;

Air Code of Ukraine dated May 19, 2011 No. 3393-VI // Bulletin of the Verkhovna Rada of Ukraine. - 2011. - № 48-49. - Art. 536 etc.

The final goal of the transfer is to construct a legislation holistic system with a branch internal structure.

The branch of legislation should strive to the maximum simplification that is the cancellation of normative-legal acts duplicating each other; replacement of several acts regulating similar legal relations with one, general; uniting several legal acts on related legal relations into one. It is reasonable when one communicative code regulates public relations in a certain area. Such structure of the legislation system does not create any contradictions. It is simple, understandable, and consistent with the axioms of the law theory and sociology. 
A clear hierarchy of laws and regulations will provide an opportunity to optimize the national legislation system.

Legislation is nothing but formal rules of law. Therefore, the specialists pay very careful attention to the internal structure of legal norms. In the law theory, formed over the past three millennia, at a scientific level, tested by the time and practical work of generations of lawyers, a number of rules have crystallized, as well as presumptions and principles that can be regarded as axioms of law.

The axioms of law are connected with each other and in a certain configuration are formed in the theorems. At the scientific level, their material manifestation is views, concepts, scientific approaches, and scientific schools. In the social sense, they have the form of institutions, regimes, branches of legislation. In the law-regulatory and lawenforcement area, they are manifested in the form of norms, laws, codes and legal systems. The interdependence and mutual influence of these manifestations is undoubted.

The basis of the legal system is, certainly, an idea. The idea of the supremacy of law is the basis of legal understanding, the right to creation and law enforcement. Justice is the key stone of relations in society manifests itself at all levels of social structure, it is genetically perceived by every person at the mental level. And it must manifest itself in all manifestations of law starting from a certain legal norm and up to the whole system of legislation.

The law theory emphasizes the importance of three-element construction of the legal norm (hypothesis, disposition, and sanction), the unity and interaction of their parts. The construction of legal norms must include the mandatory presence of all three elements in one legal act. This approach ensures the logic and completeness of legal regulation, simplifies law enforcement and reduces the degree of overregulation of social relations, since there is no need to "multiply" numerous by-laws.

It should be reminded that the legal norm does not necessarily have to be contained in one (individual) article of the normative-legal act. The hypothesis, and sometimes the disposition may be in one part of the law or by-law, and the sanction - in another, for example, in a separate section "Responsibility in the field of ..." However, in overwhelming majority, the legal norm must be within one normative legal act. And with only a 
few exceptions, when there is a necessity to take into account specific legal relations, one can use blanket norms.

This way, the structure of the communication code must include the following parts:

General part (general provisions - terms used, rules of conduct in the socio-economic field);

Special part (substantive norms - misconduct and sanctions for their commitment);

Specific part (peculiarities of proceedings in cases on misconduct in the socio-economic field exactly, regulated by the communicative code).

In a series of monographic studies and handbooks, the authors identify the branches of legislation with branches of law. And on the basis of the normative acts analysis they come to the conclusion about the existence of economic-administrative, financial-administrative and even administrative-land law. In particular, the emergence of financial law was due to constitutional, administrative, private law and economic science.

Financial law regulates relations in the field of financial activity of the state, first of all, activities on accumulation and distribution of funds, constituting the national income of the state. The administrative-legal method is applied to regulate the relations arising here. However, financial law is recognized as an independent branch, since the regulation of the mobilization, distribution and use of funds in the public interest is of great importance and it has some specific features. Thus, when it comes to the distribution of finance - this is financial law; when it is about the work organization of state financial bodies - this is administrative law.

The inevitable European integration of Ukraine predetermines decisive actions within the state to bring the current legislation in compliance with the international standards for the protection of human and citizen rights and freedoms in relations with the state. Increasing the responsibility of public authorities for the efficiency and integrity of providing administrative services is a requirement of modern Ukrainian society, a condition for the statehood maintenance and one of the fundamental principles of the administrative-legal reform initiated by the relevant Concept in 1998.

The result of internal and external structuring should be legislation that meets all the canons of norm-making techniques with minimal use of blank and reference norms. The only algorithm of the "whole" is repeated 
in all its "parts". Thus, the effect of self-regulation of the legal regulation system is achieved as the most objective, apolitical and theoretically verified format. A clear hierarchy of normative acts, the compliance of the Codes not only with the form but also with the content that they include, will contribute to the effective implementation of the principles enshrined in the Constitution of Ukraine.

\section{The Concept of Administrative Law Reform is the Basis for Public Law Development in Ukraine}

The ideological foundations of the Soviet system of law failed to meet the requirements of the time. A hierarchical approach to constructing administrative law as a branch of law that covers all areas of public life was false. The degeneration of law in the strict management of society through the use of power orders and administrative penalties led to a complete collapse and decline of the country. And today's reception of Soviet law, manifested in the scientific, educational, law-making and lawenforcement areas, impedes the construction of civilized civil relations.

Among the number of reasons for such conditions is an imperfect legal system in Ukraine, created during the Soviet period of the state existence, that is, the reception of Soviet law, which, at the time of its formation in the early 20 s of the 20th century, categorically abandoned civilization achievements in constructing its own legal system. So, Soviet law served the administrative-command system of state administration and fully met the needs of society of that time for 70 years. In the Soviet Union, an attempt was made to invent the "other law", based on party ideology that was above the law, and the state regulated all areas of public life. In such a totalitarian system, law not only lost its natural integral role as the regulator of public relations, but also turned into an instrument of influence of state power on citizens (to be exact, groups of party functionaries who usurped power and created a hierarchical bureaucratic pyramid). At that time, the average person had a feeling that the state fully met their needs. A person was dissolved in the state, ceasing to be an individual.

Soviet legal scholars rejected the civilization achievements of the philosophy of Roman law, even in the very changed form in which it 
existed in Eastern Europe 9 . The division of civil law into public and private one was considered to be mistaken. The law could only be public and responsibility was the response to violation of the rules established. If the violation of law was significant - it led to criminal responsibility, if insignificant - then to administrative one. All other relations between citizens were recognized as civil relations. Such a simplified system led not only to a misunderstanding of law as a system, but to distortion of its essence in the minds of citizens, the appearance in legislation of twisted norms on the responsibility for collecting spikes or for doing karate.

Today, not only the norms and laws adopted in Soviet times, but also the approaches to the law have remained in force. The imperfection of legal norms was, first of all, used by those sectors of society in which power levers were concentrated. Under these circumstances, corruption, "telephone law", "white-collar crime" became an obstacle to all social transformations, and, accordingly, those factors brought to nothing all the innovation changes. The administrative responsibility of ordinary citizens for minor acts in the face of total neglect of law orders by the power representatives and local self-government bodies caused legal nihilism and degradation of society. The absence of clear division of public and private relations, inconsiderate borrowing of legal norms in the imperfect post-Soviet social system led to the lack of a single interpretation of legal norms.

The reception of Soviet law manifests itself in outdated conceptual approaches, mummification and reanimation of insignificant norms, and the use of regressive approaches in education. And all this, multiplied by total corruption, leads to extremely negative consequences in the life of society. At present, "new" ways to revive the norms and approaches to the rule of law in the field of public administration lead to further deepening of the crisis phenomena in society.

What should we do when the Soviet model of the legal system and the legislative system is out of date, and the modern model no longer corresponds to either this outdated or the classic European model, and most essentially - does not meet the current realities of our life? How to get out of the dead end, where branches of law and branches of legislation conflict with each other? What should be done in a situation where the

\footnotetext{
${ }^{9}$ Підопригора О.А. Римське право : підручник / О.А. Підопригора, Є.О. Харитонов. - К. : Юрінком Інтер, 2007. - C. 103.
} 
branches of power have "atrophied" and "knitted" together and the state tree itself is no longer nourished by the juices of people's sovereignty, but turns into "twists", not capable of normal life in accordance with the Constitution, international standards and universal human values? Of course, each specialist may give their own recipes; we will consider the legal aspect of the issue. Law is a cementing, consolidating substance without which the state can not exist.

The main task that both legal science and legislative and executive bodies face is the comprehensive, reasonable and consistent revision of legislation, bringing it to the modern European standards. In our opinion, one should, firstly, adhere to the postulates and the axioms of law, both during norm-making and law enforcement; and, secondly, ensure the maintenance of those achievements of social protection, which were received, including during the Soviet period of the history of the state, based on the legal traditions of Ukrainian people. State and citizen have both rights and obligations to each other. Harmonization of legislation is the first step towards civil society.

The role of the Constitution in the implementation of administrative reform is decisive, since the Constitution of Ukraine itself requires the adoption of a number of new laws on the public power functioning as for bringing it in compliance with the norms of the Basic Law of the effective administrative legislation, development of the administrative justice institute, and development of a new administrative and legal practice by the administrative apparatus, which would put a person as the highest constitutional social value in the state in the center of attention of both executive bodies and the entire mechanism of public administration ${ }^{10}$.

The provision of Article 6 of the Constitution on the clear division of three branches of power, namely, legislative, executive and judicial power with a transparent mechanism of constraints and balances must be recognized as the axiom. The role of the executive power branch should be focused on the administration of executive and regulatory activity, which involves, among other things, the removal of unusual function of norm-making. It is about creating new mandatory rules of conduct, which are actively produced by the executive power branch today, sometimes replacing or changing the essence of the current legislation.

\footnotetext{
${ }^{10}$ Кампо В.М. Деякі проблеми адміністративної реформи в Україні / В.М. Кампо // Державноправова реформа в Україні : матер. міжнар. наук-практ. конф. - К. : Ін-т законодавства Верховної Ради України, 1997. - С. 218-220.
} 
We emphasize that the branches of power in no way should be crossed with each other, complement each other and influence one another. In fact, they must be a system of counterweights and constraints.

In this system, the people should create (elect) both legislative power (deputies of all levels) and executive power through elections (the heads of local authorities directly and central government authorities through deputies, to whom they delegate powers) and, of course, judicial power (electing by a direct vote of judges for administration of justice within the specified time). In this case, justice as the highest social value, manifested in the old saying "the law is strict, but this is the law", will be understood and acceptable to every member of society.

In Soviet law, the Code on Administrative Offences of Ukraine played the role of the system-forming law. Legal norms regulating relations in various socio-economic domains were contained in various acts, mostly by-laws (regulations, rules, instructions, orders, and even letters or teletype messages).

The immediate beginning of the administrative reform in Ukraine was adoption of the Presidential Decree "On the State Commission for the Conduct of Administrative Reform in Ukraine"11 dated 02.10.1997 № 1089. The very concept of administrative reform was approved by the Decree of the President of Ukraine dated 22.07.1998 № 810/98 ${ }^{12 .}$ In general, this concept defined the strategy and organizational and legal principles of reforming the system of state administration, the stages of administrative reform implementation. The State Commission has managed to prepare a document that envisages the creation of a more efficient apparatus of state administration, laying the basis for reforming the civil service and administrative-territorial organization of Ukraine.

Administrative reform includes three important components:

- Number one is the reform of the system of state administration,

- Number two is the reform of legislation,

- Number three is the reform of administrative law.

To achieve the goal of the administrative reform the following tasks were defined during its conduct:

- Formation of the effective organization of executive power at both central and local levels of governance;

\footnotetext{
${ }^{11}$ Концепція адміністративної реформи в Україні. - К. : ДВПП Міннауки України, 1998. - 62 с.

12 Про заходи щодо впровадження адміністративної реформи в Україні : Указ Президента України від 22.07.1998 р. № 810/98// Офіційний вісник України. - 1999. - № 21. - С. 32.
} 
- Formation of a modern system of local self-government;

- Introduction of a new ideology of the executive and local selfgovernment functioning as activities to ensure the implementation of rights and freedoms of citizens, the provision of state and public services;

- Organization of civil service and service in local self-government bodies on the new principles; creation of a modern system of training and retraining of administrative personnel;

- Improvement of the administrative-territorial system.

Codification has become one of important parts of the legal reform in Ukraine as a way to systematize legal acts. Adoption of the codified normative acts was carried out by means of processing and compilation of legal norms in logically agreed normative legal acts that govern a certain field of public relations at the branch level systematically and in full:

- 2002 (came into force on 01.01.2004) - The Customs Code of Ukraine (Bulletin of the Verkhovna Rada of Ukraine, 2002, № 38-39, p. 288); 2012 - a new version of the Customs Code of Ukraine (Bulletin of the Verkhovna Rada of Ukraine, 2012, № 44-45, № 46-47, № 48, Article 552);

- 2005 - The Code of Administrative Legal Proceedings of Ukraine (Bulletin of the Verkhovna Rada of Ukraine, 2005, № 35-36, № 37, Article 446);

- 2011 - The Tax Code of Ukraine (Bulletin of the Verkhovna Rada of Ukraine, 2011, № 13-14, № 15-16, № 17, Article 112)

became the stages of administrative law reform.

In 2010 the wide-scale reformation of the system of executive power bodies was started. ${ }^{13}$ First of all, it was proved by the adoption of the Presidential Decrees "On Optimization of the System of Central Executive Power Bodies" of the Optimization of the System of Central Executive Power Bodies"15 dated 06.04.2011 № 370/2011, as well as adoption of the Laws "On

\footnotetext{
${ }^{13}$ Комзюк А.Т. Напрямки розвитку адміністративного права України в контексті пріоритетного забезпечення прав і свобод людини і громадянина [Електронний ресурс] / А.Т. Комзюк. - Режим доступу: http://www.nbuv.gov.ua/.

${ }_{14}$ Про оптимізацію системи центральних органів виконавчої влади : Указ Президента України від 09.12. 2010 p. № 1085/2010 [Електронний ресурс]. - Режим доступу: http://zakon3.rada.gov.ua/laws/show/ $1085 / 2010$.

${ }^{15}$ Питання оптимізації системи центральних органів виконавчої влади : Указ Президента України від 06.04.2011 р. № 370/2011 [Електронний ресурс]. - Режим доступу: http://zakon3.rada.gov.ua/laws/ show/370/2011.
} 
Central Executive Power Bodies” on 17.03.2011 № 3166-VI ${ }^{16}$, “On the Cabinet of Ministers of Ukraine” on 27.02.2014 № 794-VII ${ }^{17}$.

Today we have the Strategy for Sustainable development "Ukraine 2020" approved by the order of the President of Ukraine on 12.01.2015 № $5 / 2015^{18}$, defined the reform of state administration, namely, the construction of transparent system of state administration, the creation of state service professional institution, its efficiency provision as a goal of the primary reforms. The result of the reform implementation should be creation of an efficient, transparent, open and flexible state administration structure with the use of the latest information and communication technologies (e-government) capable of producing and implementing a coherent state policy aimed at sustainable social development and adequate response to internal and external challenges.

Today, many things have already been done. The various types of central executive bodies (ministries, state committees and central executive bodies with special status) are classified and regulated, it is determined that the ministry is the supreme body in the system of central executive power bodies. Significant steps were also taken in improving the civil service system, revision of the administrative and territorial structure of the state; measures were taken to strengthen the guarantees of local self-government, and adopted a program of its state support.

The Strategy for Sustainable Development "Ukraine-2020" has given an equal priority to the reform of state administration as well as decentralization of power. Such step should re-structure the relations between the state and society, changing their vector. The autonomy of local self-government and the completeness of power in solving local issues, self-sufficient administrative-territorial units and budget autonomy generate the illusion of such desirable freedom. Freedom from state interference, arbitrariness of officials, exaggerated fiscal policy.

\section{CONCLUSIONS}

The large-scale administrative-legal reform conducted within the reasonable terms may finally trigger the mechanism of state

\footnotetext{
16 Про центральні органи виконавчої влади : Закон України від 17.03.2011 р. № 3166-VI // Відомості Верховної Ради України (ВВР), 2011, № 38, ст. 385.

${ }^{17}$ Про Кабінет Міністрів України: Закон України від 27 лютого 2014 року № 794-VII // Відомості Верховної Ради України (ВВР), 2014, № 13, ст. 222.

${ }^{18}$ Про Стратегію сталого розвитку «Україна - 2020»: Указ Президента України від 12.01.2015 р. № 5/2015 [Електронний ресурс]. - Режим доступу: http://zakon5.rada.gov.ua/laws/show/5/2015.
} 
administration of a new pattern, namely, the mechanism of administration of democratic law-governed and social state.

It is necessary to go through the following stages:

- To define clearly the subject, methods and the system of administrative law and to clear it up from relations that are unnatural to it;

- To systematize administrative law in accordance with the subject of administrative law defined, releasing it from legal norms of other branches;

- To consolidate the status of self-government administrative bodies by legal norms, taking into account the distribution of powers.

The steps to bring Ukrainian legislation to the world standards should take place in a complex and coordinated manner and avoid creating additional conflicts in the national legal system. The transparency of this process should be ensured by extensive discussions with the public as well as scientific community and popularization of law-making actions of authorities among the people.

The proposed approach should create a theoretical basis for creation of a system of normative-legal acts in the field of responsibility for public misconduct. In accordance with the hierarchy of normative legal acts, the construction of this system should go from the Basic law, covering the basic principles, concepts and stages of proceedings in cases of public misconduct. In the future, laws and by-laws adopted in compliance with the provisions of the Basic law will require technical improvements in compliance with the requirements of norm-making techniques and international standards.

\section{SUMMARY}

The article describes the directions of improvement of national legislation in Ukraine. The Constitution of Ukraine laid the basis for the development of Ukraine as a highly developed, legal, civilized European state with a high standard of living, culture and democracy, in which the principle of the supremacy of law acts and all public relations are based on legal orders.

The steps to bring Ukrainian legislation to the world standards should take place in a complex and coordinated manner and avoid creating additional conflicts in the national legal system. The transparency of this process should be ensured by extensive discussions with the public as well 
as scientific community and popularization of law-making actions of authorities among the people.

The proposed approach should create a theoretical basis for creation of a system of normative-legal acts in the field of responsibility for public misconduct. In accordance with the hierarchy of normative legal acts, the construction of this system should go from the Basic law, covering the basic principles, concepts and stages of proceedings in cases of public misconduct.

\section{Information about the author: \\ Petkov S. V.}

Doctor of Juridical Sciences, Professor, Director at the Department of Regional Offices of the Secretariat of Ukrainian Parliament Commissioner for Human Rights 21/8, Instytutska str., Kyiv, Ukraine 